\title{
Seminal Vesicle Soft Tissue Neoplasm
}

National Cancer Institute

\section{Source}

National Cancer Institute. Seminal Vesicle Soft Tissue Neoplasm. NCI Thesaurus. Code C161637.

A mesenchymal neoplasm that arises from the seminal vesicle. 